Theories \& Applications, the International Edition

Printed Version: (ISSN 2090-5262)

Online Version: (ISSN 2090-5270)

March 2013, Volume 3, No. 1 Pages (94 - 109)

\title{
The Effect of Developing Endurance over Some Biochemical Changes and the perfection of Forehand Killing Shot with regard to the Squash Junior
}

\author{
Mohamed Ahmed Abd Allah Ibrahim*, Khaled Naeem Ali Mohamed**
}

\begin{abstract}
* Professor of tennis sports in the department of theories and applications, tennis sports-Faculty of Physical Education for boys - Zagazig University.

** Teacher in the department of sports training -Faculty of Physical Education for boys-Helwan University.
\end{abstract}

\begin{abstract}
The research aimed at setting down a proposed training schedule to improve (muscular respiratory and periodical endurance and getting to know its effect on the following things :

1-Biochemical changes (Beta-Endorphins -Lactic acid-LDH) in relation to 15 years squash player.

2- Perfection of forehand killing shot with regard to 15 years squash player.

The researcher used experimental methods on a sample of eight (8) squash juniors under 15.Among methods of research :biochemical measurements -tests of talented-the proposed training schedule .The researcher used the following statistic terminology: Mean -Standard Deviation -Median Skewers-Correlation Coefficients -"T" test-Ratios \& Rates test.

Crucial conclusions of the research:

1- The proposed training schedule for improving endurance affects positively on biochemical changes (Beta-Endorphins -Lactic acid-LDH) in relation to the squash player under 15.

2- There are better averages of improvement in the after training measurement than the before training measurement in biochemical changes (Beta-Endorphins -Lactic acid-LDH) .These averages ranged between (16.7\%: 10.97) with regard to the squash player under 15.

3- The proposed training schedule for improving speed in a positive way with a statistic significant affects on the perfection of forehand killing shot with regard to the squash player under 15.

4- There are better averages of improvement in the after training measurement than the before training measurement in relation to the perfection of forehand killing shot of the squash junior under 15 which ranged between (90.79\%:66.67\%)
\end{abstract}

\section{Introduction and subject of the research:}

$\mathrm{I}^{\mathrm{n}}$ recent times the field of sportive training witnesses a rapid development related to the specific information of fitting the sportsman. The results associated with these information appear in achieving sportsmen high levels, wherein the scope of sportive training aims essentially at developing the level of sportive performance through developing the functions of the various body systems and there ability for the dynamic performance with husbanding the exerted effort. This operation is called "physiological adaptation". But this can be only achieved through regular training which leads through physiological changes it creates to the achievement of both husbanding the effort of the sportsman and realizing best results.

During the physical performance of the player some biochemical changes happen, and such kind of changes differ according to different training loads, and this needs, in turn , understanding vital natural and chemical bases upon which these changes rise .Consequently they can be functioned in controlling and increasing the effectiveness of these training schedules for athletes.(112:5)

One of the physiological changes that happen in the course of sportive training is the formation of lactic acid. The concentration of lactic acid at the time of rest ranged between 10-20 millimeter mol and100 centimeter3.The Lactic 
acid increases according to the load and exerted effort.It is worth mentioning that lactic acid results from the stored up glycogen in muscles and it splits so as to produce energy and form Lactic acid (172:30).

The increase of Lactic acid results in muscles tiredness and consequently affects on the continuation of muscles to do there performance. (11:34)

The sportive training has a great effect on improving the ability of muscles for exerting effort and helps delaying tiredness. On other words, once the level of the player increases the rise of tiredness delayed and this helps getting rid of Lactic acid which is converted to Berophic ,as the Beta-Endorphins (the morphine of blood) works as a chemical transporter and organizes various kinds of psychological operations and helps to the increase of the secretion of some other hormones ,such as, glycogen and Ansoline.At the same time, the secretion of internal morphine increases with tension (357-)28)

Both of Alan Marion (1989) and Wael Kandil agree with each other that there are some essential physical elements upon which the sport of squash depends on. These elements are (the periodical respiratory endurance, the speed of reaction, grace, ability, flexibility and extreme power (48:21) (40:23)

Both aerial and non-aerial endurance are considered to be two of the most important physical features that help in continuing performance efficiently in most of the activities that do require exerting effort sequentially or intermittently for long periods.(67:3)

Nick and Malcom (1994) mention that endurance means the ability to exert effort that requires systoling of muscles so as to send out a moderate power or less than the maximum power for long periods, wherein this needs an adaption with the functions of heart and lungs to face up the exerted effort. (102:32)

Abou El Ella Abdel Fatah points out that the high physical level of the athlete is a result of functional and genetic changes that happen in internal systems .Due to these changes the functional ability of player increases, hence ,the physical and skillful level of this player increases.(145:2)

It is always said that the sport of squash is the battle of endurance, as actually the periodical respiratory endurance is one of the most important constituents of physical fitness in relation to the squash player. Whenever the quantity of Oxygen that reaches muscles increases, the effort exerted from the player increases, and the chance to be tired soon decreases and vice versa. In this place the importance of periodical endurance becomes clear for the squash players as it does represent the bases upon which other elements are based on. That is why squash is a sport that has no time limit to be played in, and this made periodical endurance is the most important element in the physical fitness for the squash players. (114:29)

The forehand killing shot is considered to be one of the strongest shots that has some spinning and is directed at the front wall almost above the net and if possible with an angle. It is very important and vital to shoot low over the front wall, as when it is shot in a high position this makes it rebound high in the middle to be a good chance for the competitor. That is why the time to use it is important and the player should be trained well to exercise it before the matches. (167:8)

The problem of the research resulted through the observation of two researchers to the inaccurate offensive shots, in particular, the forehand killing shot of the squash junior under 15 which is a very important problem. A great work should be done in order to find scientific solutions for this problem through working out codified training schedules. As we have said earlier, the squash sport is one of the sports that puts a heavy burden over functional systems of squash players, so it is necessary for them to have the functional efficiency for all body systems, in particular, the periodical and respiratory systems, so as to be able to continue the good performance and competition during the life time of the match.Munir Gerges(2004) gives emphasis that the physically and functionally unfit player appears to be tired and he loses the ball so many times., not to mention the weakness of planning or the absence of it.

On the contrary, the player who is physically 
and functionally fit finishes the match as he began it and controls the ball and thinks in a sound way during his skillful and planned performance. (43:20)

What's more Essam Edin Al Weshahy (1983) adds that concentration in an early age helps the trainer to reach with the player to the utmost physical and technical fitness. That's because the juniors can adapt psychologically as the perfect technical performance happens only at the age of (11-18 years) and this is the best time for learning and training. (16:69)

For this reason the subject of this research came into sight in a trial from both researchers to set a training schedule to improve endurance (muscular endurance-periodical respiratory endurance) and to get to know its effect on some biochemical variables, such as, (BetaEndorphins-Lactic acid-LDH"the enzyme which takes off the Hydrogen") and the perfection of forehand killing shot with respect to the squash junior under 15.

\section{Objectives of the research:}

This research aims at working out a proposed training schedule so as to improve endurance (muscular-periodical-respiratory) and to get to know its effect on:

\section{1-Biochemical changes (Beta-Endorphins-}

Lactic acid-LDH) with respect to the squash junior under 15.

2-The perfection of forehand killing shot with respect to the squash junior under 15 .

\section{Connected studies:}

Laila Abd El Baky (1996) made a study aimed at getting to know the effect of physical effort on the enzymes of Tran's amines and LDH of running and jogging athletes and their connection to the numerical standard. The researcher used the experimental method to compare between a sample of (30) players of short and long distance races and students who do not practice sport at all. Among methods of research: Biochemical measurements-samples of blood. One of the most important results: the increase of LDH related to the two groups of short and long distance races. Besides there was connection between the numerical standard and differences between the before and after measurements for the LDH enzyme. (17)
Wael Mohamed Ramadan (1998) made a study aimed at getting to know the effect of a proposed schedule to improve speed endurance over the unareal mark of identification and the standard of the numerical achievement for the athlete of 800 meter running. The researcher used the experimental method on (8) players. Among methods of research: physical testssamples of blood. One of the most important results :there are some significant differences between the before and after measurements for the sample of research in physiological changes (the maximum average for the consumption of Oxygen -Lactic acid ) and the standard of the numerical achievements for the athletes of 800 meter running in favor of the after measurement process. (22)

Adel Mohamed Abd El Menem (1999) made a study aimed at getting to know the effect of a training schedule through the Lactic acid endurance on some physiological and biochemical changes in relation to short distance swimming. The researcher used the experimental method on (65) swimmer (33 males-32 females) among methods of research: physiological and biochemical tests-samples of blood. One of the most important results :that there are some significant differences between the before and after measurements for the experimental group in the standard of concentration of Lactic acid and the numerical standard for short distance swimming in favor to the the after measurement process.(14)

Angelo Poulos (2001) made a study aimed at getting to know the effect of over load training on the concentration level of Beta-Endorphins. The researcher used the experimental method on a sample of (9) atheletes.Among methods of research: biochemical measurements -sample of blood. One of the most important results: that the over load during the time of training increases Beta-Endorphins in blood. (24)

Bentley and others (2001) made a study aimed at getting to know the effect of Lactic acid on blood in the course of training. The researchers used the experimental method on a sample of eight (8) high level atheletes.Among methods of research: biochemical measurements - samples of blood. One of the most important results: is that whenever the period of training increases, 
the accretion of Lactic acid increases in blood. (25)

Burke and others (2001) made a study aimed at comparing between the effect of two training schedules on the average of Lactic acid and the level of aerial changes. The researchers used the experimental method on a sample of twenty one (21) women on the bases of the highest level for the maximum consumption of Oxigene.Among methods of research: biochemical and physiological tests -samples of blood. One of the most important results: is that over load trainings with the method of high standard periodical exercise affected in a positive way on the standard of concentration of Lactic acid in blood. (27)

Meyer and others (2001) made a study aimed at identifying the effect of over load training on the excretion of Beta-Endorphins. The researchers used the experimental method on a sample of eight (8) atheletes.Among methods of research: biochemical measurements-samples of blood-the proposed training schedule. One of the most important results: the concentration of Beta-Endorphins does increase whenever there is an increase of over load exercises during training. (31)

Abeer Gamal Shehata (2002) made a study aimed at identifying the effectiveness of two methods which form an over load training on the concentration of Lactic acid and some physiological and physical changes and the numerical level of the 400 meter free style swimming .The researcher used the experimental method on a sample of (42) swimmer under 12.Among methods of the research: physiological and biochemical tests samples of blood. One of the most important results: the existence of some significant differences in the level of the concentration of Lactic acid and the numerical standard of the 400 meter free style swimming. (15)

\section{Procedures of the research:}

\section{Method of the research:}

The two researchers used the experimental method through an experimental pattern for one group and that is by using both the before -after measurements for the reason of suiting the nature and purposes of this recent study.

\section{Sample of the research:}

A sample of the research was chosen intently and it included (18) squash juniors under (15).They were listed in the following sports institutions and boards: Heliopolis Club and Maadi Club in Cairo governorate. These two clubs are registered in the Egyptian Federation of Squash in season 2011/2012. Ten juniors were set aside to make an exploratory study over them. Therefore, the basic sample of the research would be (8) eight squash juniors under 15.

\section{Reasons for choosing the sample:}

- The second researcher trains the individuals of the research sample.

- The juniors show up to give samples of their blood.

\section{The moderation of the distribution of the research samples:}

The members of the research sample were organized to be homogeneous in the following variables :( age - the training age -length weight).Both the biochemical changes and the perfection of forehand killing shot included in the research were tested. Table no. (1) Highlights such kind of things. 
Table no. (1)

The moderation of the distribution of the research samples in the average of growth in relation to the research and the perfection of forehand killing shot.

$\mathrm{N}=8$

\begin{tabular}{l|l|l|l|l|l}
\hline \hline VARIABLES & $\begin{array}{l}\text { Calculation } \\
\text { Unit }\end{array}$ & Mean & $\begin{array}{l}\text { Standard } \\
\text { Deviation }\end{array}$ & Median & Skewers \\
\hline \hline Age & year & 14.00 & 0.68 & 13.80 & 0.88 \\
\hline Training age & year & 4.12 & 0.95 & 3.90 & 0.69 \\
\hline Length & centimeter & 162.50 & 4.73 & 161.00 & 0.95 \\
\hline $\begin{array}{l}\text { Weight } \\
\text { The forehand } \\
\text { killing shot }\end{array}$ & Kilo gram & 54.15 & 5.21 & 53.50 & 0.37 \\
\hline $\begin{array}{l}\text { From the } \\
\text { cross shot }\end{array}$ & degree & 1.63 & 0.87 & 1.50 & 0.45 \\
\hline $\begin{array}{l}\text { From the } \\
\text { straight } \\
\text { length shot }\end{array}$ & degree & 0.33 & 2.00 & 0.91 & 2.10 \\
\hline $\begin{array}{l}\text { From the lop } \\
\text { shot }\end{array}$ & degree & 0.76 & 1.50 & 0.99 & 1.75 \\
\hline \hline
\end{tabular}

Table no. (1) shows that all values of standard deviations for growth and the perfection of forehand killing shot are ranged between (0.95:0.33) which means that it is reducible to $\left(3+_{-}\right)$. No matter it does indicate the moderation of the distribution of the research samples in these variables.

Table no. (2)

The moderation of the individuals of the research samples in biochemical variables related to the research.

$$
\mathrm{N}=8
$$

\begin{tabular}{l|l|l|l|l|l}
\hline \hline Variables & $\begin{array}{l}\text { Calculation } \\
\text { Unit }\end{array}$ & Mean & $\begin{array}{l}\text { Standard } \\
\text { Deviation }\end{array}$ & Median & Skewers \\
\hline \hline $\begin{array}{l}\text { Beta- } \\
\text { Endorphins }\end{array}$ & $\begin{array}{l}\text { Be co- } \\
\text { mol/liter }\end{array}$ & 9.99 & 0.21 & 9.94 & 0.71 \\
\hline Lactic acid & $\begin{array}{l}\text { Millimeter- } \\
\text { mol/liter }\end{array}$ & 6.86 & 0.10 & 6.83 & 0.90 \\
\hline L D H & Unit liter & 589.41 & 23.75 & 583.69 & 0.72 \\
\hline \hline
\end{tabular}

Table no. (2) shows that all values of standard deviations in biochemical changes (Beta-Endorphins -Lactic acid LDH ) related to the research are ranged between $(0.71: 0.90)$ which means that it is reducible to $\left(3+_{-}\right)$. No matter ,it does indicate the moderation of the distribution of the research samples in these variables. 

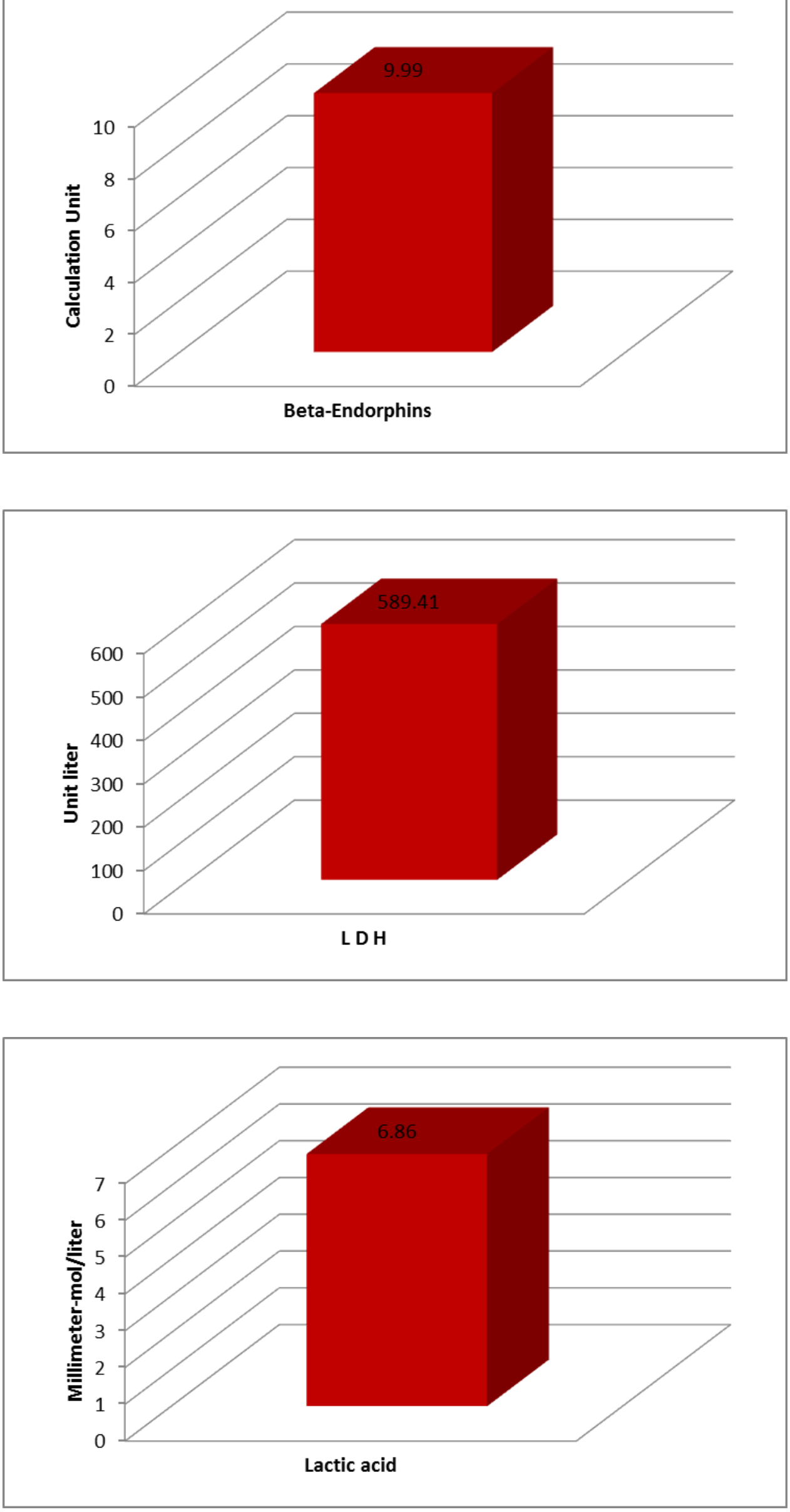


\section{Tools of collecting information:}

Tools of collecting information are divided as follows:

First: Tools and equipments used in research:

-The Rasta meter to measure the whole length of the body.

-Medical scale foe weighing the body.

-Centrifugation system, 3000 rotations in a minute to separate plasma.

-Gamma system to measure Beta-Endorphins in blood.

-A system to analyze Lactic acid in blood and a Spectrophotometer.

-Heparin for blood anti-coagulation.

- (3) 3 centimeter use and throw plastic syringes to drag blood samples.

-Numbered testing tubes to collect blood samples.

-Kits to check up Lactic acid in blood.

-Stop watches to measure time to $1 / 100$ seconds.

-Ice box to keep blood and transfer it.

-Medical cotton, plaster, and antiseptics.

-Squash court, rackets and legal balls.

-Training funnels.

-Medical balls.

-Benches.

-Sandy balls.

-A system for determining weight.

\section{Second: Biochemical measurements related to research:}

A three centimeter sample of blood was dragged by a doctor specialized in medical analysis from the anticubital veins of each junior through sterilized use and throw syringes. That was after the first exercise in the proposed training schedule. Six centimeter 3 of blood was dragged from each junior during the application of before and after measurements. Samples of blood were taken in sterilized clean plastic tubes. All tubes were numbered with an ink pen, organized and put in sequence inside an analysis box. Each and every plastic tube took a certain number. Samples of blood were transferred to the lab so as to separate the serum from the cells through a scientific codified centrifugation system with a centrifugation power of 3000 rotation per minute and this was for five (5) minutes .Tubes were set inside the system in a balanced way to measure the concentration of Beta-Endorphins, Lactic acid and LDH IN Blood.

\section{Third: Tests of the perfection of forehand killing shot: appendix (1)}

The two researchers used tests of the perfection of the forehand killing shot which measures the perfection of this talent through various kinds of attacks that are connected to it (the straight length shot -the lop shot -the serve )These tests were prepared by Ehab Saber (2009) (41).

\section{The first exploratory study:}

The two researchers made the first exploratory study from the period 02/03/2012 up to $03 / 05 / 2012$ on a sample of ten (10) squash juniors from the basic inside and outside sample of the research and this aimed at getting to know the following things:

1-If the applied tests were compatible with the individuals of the research sample or not.

2-Carrying out scientific dealings (honesty firmness) connected to the tests of the research.

\section{Scientific dealings (honesty - firmness) for tests of the research:}

The two researchers used the honesty of distinction in favor of the honesty modulus between two groups. On of them was distinctive and contained (ten (10) squash juniors under 17).This was through the application of talents tests related to the research. While the other group was not distinctive and contained (ten (10) squash juniors under 15). The calculation of value " $\mathrm{T}$ " between the members of the two groups, the distinctive one, and the nondistinctive one concerning the talents variables were done .Table no. (3) Makes such thing very clear. On the other hand, the method of applying the test and repeating it was used to calculate the firmness modulus. However, the information of honesty modulus for the non-distinctive 
group was used as a primary application. The application was repeated afterwards on the same sample but this was after five (5) days from performing the first application. But that was on the condition that the calculation of the correlation coefficients should be between the two results of applications, the first and the second. Table no. (4) Makes such thing very clear.

Table no. (3)

The honesty modulus for the tests of the perfection of the forehand killing shot in squash:

Non-distinctive group $\quad \mathrm{N}=10 \quad$ Distinctive group

\begin{tabular}{l|l|l|l|l|l|l}
\hline \hline Variables & Calculation unit & $\begin{array}{l}\text { Av. Of } \\
\text { calculation }\end{array}$ & $\begin{array}{l}\text { Standard } \\
\text { deviation }\end{array}$ & $\begin{array}{l}\text { Av. Of } \\
\text { calculation }\end{array}$ & $\begin{array}{l}\text { Standard } \\
\text { deviation }\end{array}$ & $\begin{array}{l}\text { Value of } \\
\text { "T" }\end{array}$ \\
\hline \hline $\begin{array}{l}\text { The forehand } \\
\text { k. shot }\end{array}$ & & & & & & \\
\hline $\begin{array}{l}\text { From the } \\
\text { cross shot }\end{array}$ & degree & 5.30 & 1.83 & 1.50 & 0.55 & 5.94 \\
\hline $\begin{array}{l}\text { From the } \\
\text { straight length } \\
\text { shot }\end{array}$ & degree & 6.20 & 1.90 & 2.10 & 0.89 & 5.86 \\
\hline $\begin{array}{l}\text { From the lop } \\
\text { shot }\end{array}$ & degree & 6.10 & 1.77 & 1.60 & 0,63 & 5.23 \\
\hline \hline
\end{tabular}

The value of "T" according to Metwi 2.101=0.05

"D"at the level of 0.05 .

Table no. (5) Makes it obvious that there are significant differences at the level of 0.05 between the two groups, the distinctive and non-distinctive one in favor of the first group in relation to the forehand killing shot in squash sport. All of this points out to the rightness of tests of the research.

Table no. (4)

The firmness modulus for the tests of the perfection of the forehand killing shot in squash sport.

Second application $\quad \mathrm{N}=10$ First application

\begin{tabular}{l|l|l|l|l|l|l}
\hline \hline Variables & $\begin{array}{l}\text { Calculation } \\
\text { unit }\end{array}$ & $\begin{array}{l}\text { Av. Of } \\
\text { calculation }\end{array}$ & $\begin{array}{l}\text { Standard } \\
\text { deviation }\end{array}$ & $\begin{array}{l}\text { Av. Of } \\
\text { calculation }\end{array}$ & $\begin{array}{l}\text { Standard } \\
\text { deviation }\end{array}$ & $\begin{array}{l}\text { Value of } \\
\text { "R" }\end{array}$ \\
\hline \hline $\begin{array}{l}\text { The } \\
\text { forehand k. } \\
\text { shot }\end{array}$ & & & & & \\
\hline $\begin{array}{l}\text { From the } \\
\text { cross shot }\end{array}$ & degree & 1.50 & 0.55 & 1.60 & 0.72 & 0.912 \\
\hline $\begin{array}{l}\text { From the } \\
\text { straight } \\
\text { length shot }\end{array}$ & degree & 2.10 & 0.89 & 2.30 & 0.95 & 0.875 \\
\hline $\begin{array}{l}\text { From the } \\
\text { lop shot }\end{array}$ & degree & 1.60 & 0.63 & 1.70 & 0.81 & 0.908 \\
\hline \hline
\end{tabular}

The value of "R" in the table at the level of $0.05=0.623$

"D" at the level of 0.05 . 
Table no. (4) Makes it clear that there is a connection at the level 0.05 between the results of both, the first and the second application in relation to the tests of the perfection of the forehand killing shot in squash sport which points out to the solidness of the test related to the research.

\section{The proposed training schedule:}

\section{The objective of the training schedule:}

1- Improving muscular, periodical and respiratory endurance in addition to improving some biochemical changes (BetaEndorphins -Lactic acid -LDH) of the squash junior under 15

2-Improving the perfection of forehand killing shot with regard to the squash junior under 15.

\section{Bases of the proposed training schedule:}

On the basis of reading some specialized scientific references in the sport of squash (4) (18) (21) and the scientific studies (11) (14) (15) (22) the two researchers marked out some scientific bases which should be followed in setting down the training schedule. They are as follows:

-The content of the schedule should be compatible with the standard and ability of members of the research sample.

-The distribution of periods of rest and activity inside the schedule.

-Using the method of periodical training with its two types (the low standard over load-the high standard over load)

- Using the wavy method (1:1) which means one day of training with over load effort followed by a day of training with a down load effort of positive rest.

-The over load exercise in the proposed training schedule is ranged between 50\%:75: from the maximum level the junior can endure.

- Repetitions range is between (10:20) times.

-Number of groups is between one (1)minute to three (3)minutes-

-Range of the rest for groups is ranged between one (1) minute to three (3) minutes.
-Performing eight (8) exercises in daily training unit wherein the junior performs (4) exercises out of the respiratory periodical enduring training. He also performs another (4) exercises from the endurance trainings shown in appendix no. (3)

-Performing a series of talents exercises at the end of daily training unit's . The period of these trainings should be about 15 minutes.

Both Hanfy Mukhtar and (1988) and Adel Abd El Basir (1999) pointed out some scientific principles that should be followed in applying the training schedule. They are:

-Taking into consideration the successive steps covering the training load.

-Applying the principle of continuation in the training.

- Avoiding the uncalculated speed up in applying the schedule.

-Taking into consideration the process of warming up before starting the main part of the training unit. (87:13) (11:9).

\section{The second exploration study:}

The two researchers applied a weekly training unit with an average of three (3) units in a week in relation to the exploration sample. This was in the period 09/03/2012 up to $15 / 03 / 2012$. This training unit aimed at marking out the maximum over load for each junior in the proposed trainings and periods of rest among repetitions and groups. In the light of this, the content of the proposed training schedule to improve endurance was set. The schedule has been brought up before a group of experts in racket sports and sports physiology before being applied (appendix 2) they approved of the schedule with a percentage of (95).

The periodical distribution for the training schedule:

-The period of the training schedule is eight (8) weeks.

-The period of the daily training unit is (120) minutes.

-Number of times in weekly training is (3) units.

- Number of training units is (24) unit. 
The two researchers pointed out that the content of the proposed training schedule is to improve endurance of the squash junior under 15 is shown in appendix no. (3).

\section{The before training measurements:}

The before training measurements for members of the research sample in biochemical changes in the research were done after performing the first training unit in the proposed training schedule directly without a period of rest. As the biochemical changes in research appear only when muscular tiredness happens and after the tests of the perfection of the forehand killing shot in the period 16-03-2012 up to 20-03-2012.

\section{Applying the proposed training schedule:}

The content of the proposed training schedule was carried out on the members of the research sample in the period 22-03-2012 up to 16-052012 for eight (8)weeks in so much as (3) training units weekly. The sample of the research did not deal with any training schedules except the proposed training schedule.

\section{The after training measurements:}

The after training measurements for the variables of the research at the end of the last training unit in the proposed training schedule were done with the same sequence and methods of the before training measurements. This was done in the period $17-05-2012$ up to $20-12-$ 2012.

\section{Statistical treatments:}

The two researchers treated the data statistically by using the following of statistical analysis:

-Mean

-Standard Deviation

-Median

-Skewers

-Correlation Coefficient

-T. Test

Ratios \& Rates Test

Presentation of results:

The significance of the differences between the after-before measurements in relation to the research sample in biochemical changes included in the research:

$\mathrm{N}=8 \quad$ after measurement before measurement

\begin{tabular}{l|l|l|l|l|l|l}
\hline \hline variables & $\begin{array}{l}\text { Calculation } \\
\text { unit }\end{array}$ & $\begin{array}{l}\text { Average of } \\
\text { calculation }\end{array}$ & $\begin{array}{l}\text { Deviation } \\
\text { standard }\end{array}$ & $\begin{array}{l}\text { Average } \\
\text { of } \\
\text { calculation }\end{array}$ & Dev.sta. & $\begin{array}{l}\text { Value } \\
\text { of 'T' }\end{array}$ \\
\hline \hline $\begin{array}{l}\text { Beta- } \\
\text { Endorphins }\end{array}$ & $\begin{array}{l}\text { Beco.mol } \\
\mid \text { liter }\end{array}$ & 9.99 & 0.21 & 8.63 & 0.18 & 8.14 \\
\hline Lactic acid & $\begin{array}{l}\text { Millimeter. } \\
\text { Mol liter }\end{array}$ & 6.86 & 0.10 & 5.91 & 0.12 & 6.79 \\
\hline L D H & Unit |liter & 589.41 & 23.75 & 531.15 & 25.61 & 4.45 \\
\hline \hline
\end{tabular}

The value of"T" at the level of $0.05=2.145$

"D"at the level of 0.05

Table no.(5) makes it clear that there are some statistic differences at the level of 0.05 between the before training measurement and the after training measurements for the members of the research sample in biochemical changes (BetaEndorphins -Lactic acid - L D H) in favor of the after training measurement. 
Table no. (6)

Averages of improvements of the after training measurement and the before training measurement in relation to the research sample in biochemical changes included in the research.

Members of the research sample

$\mathrm{N}=8$

\begin{tabular}{l|l|l|l}
\hline \hline Variables & $\begin{array}{l}\text { Before } \\
\text { measurement }\end{array}$ & After measurement & $\begin{array}{l}\text { Averages of } \\
\text { improvements }\end{array}$ \\
\hline \hline Beta-Endorphins & 9,99 & 8.83 & $15.76 \%$ \\
\hline Lactic acid & 6.86 & 5.91 & $16.07 \%$ \\
\hline LDH & 589.41 & 531.15 & $10.97 \%$ \\
\hline \hline
\end{tabular}

Table no. (6) Makes it clear that averages of Wherein the highest average of improvement improvements in relation to the after training for the modulus of Lactic acid was estimated to measurement are better than the before training be $16.75 \%$ and the lowest average of measurements of the research sample in improvement for the modulus of LDH was biochemical changes included in the research. estimated to be $10.97 \%$ for the research sample.

Table no. (7)

Significances of the differences between the before and after measurements in relation to the research sample in the perfection of forehand killing shot in squash sport.

\begin{tabular}{l|l|l|l|l|l|l}
\hline \hline variables & $\begin{array}{l}\text { Measuremen } \\
\mathrm{t} \text { unit }\end{array}$ & $\begin{array}{l}\text { Average of } \\
\text { calculation }\end{array}$ & $\begin{array}{l}\text { Deviation } \\
\text { standard }\end{array}$ & $\begin{array}{l}\text { Average of } \\
\text { calculation }\end{array}$ & $\begin{array}{l}\text { Deviation } \\
\text { standard }\end{array}$ & $\begin{array}{l}\text { Value } \\
\text { of "T" }\end{array}$ \\
\hline $\begin{array}{l}\text { Forehand } \\
\text { killing shot }\end{array}$ & degree & & & & & \\
\hline $\begin{array}{l}\text { From cross } \\
\text { shot }\end{array}$ & degree & 1.63 & 0,87 & 3.11 & 1.01 & 3.12 \\
\hline $\begin{array}{l}\text { From } \\
\text { straight } \\
\text { length shot }\end{array}$ & degree & 2.10 & 0.91 & 3.50 & 1.16 & 3.03 \\
\hline $\begin{array}{l}\text { From the } \\
\text { lop shot }\end{array}$ & degree & 1.75 & 0.99 & 3.00 & 1.12 & 2.91 \\
\hline
\end{tabular}

Table no.(7) shows the statistic differences at the level of 0.05 between the before and after measurements for the members of the research sample in the perfection of forehand killing shot in squash sport in favor of the after training measurement. 
Table no. (8)

Averages of improvements of the after training measurement are better than the before training measurement in relation to the forehand killing shot in squash sport.

Members of the research sample $\quad \mathrm{N}=8$

\begin{tabular}{l|l|l|l}
\hline \hline Variables & before & after & $\begin{array}{l}\text { Average } \\
\text { improvements }\end{array}$ \\
\hline \hline $\begin{array}{l}\text { The forehand } \\
\text { killing shot }\end{array}$ & & & \\
\hline From the cross shot & 1.63 & 3.11 & $90.79 \%$ \\
\hline $\begin{array}{l}\text { From the straight } \\
\text { length shot }\end{array}$ & 2.10 & 3.50 & $66.67 \%$ \\
\hline From the lop shot & 1.75 & 3.00 & $71.43 \%$ \\
\hline \hline
\end{tabular}

Table no. (8) Makes it clear that there are some averages of improvements in favor of the after training measurement in the perfection of forehand killing shot in squash sport with regard to the research sample. Wherein the highest average of improvement in the modulus of the cross shot was estimated to be $90.79 \%$ and the lowest average of improvement for the modulus of the straight length shot was estimated to be $66.67 \%$.

\section{Discussion of conclusions:}

Conclusions of table no. (5) indicated that there are significant statistic differences at the level of 0.05 between the before training and after training measurements for the research sample in biochemical changes (Beta-Endorphins Lactic acid $-\mathrm{LDH}$ ) in favor of the after training measurement.

Conclusions of table no. (6) Pointed out that there are averages of improvements in favor of the after training measurement for the research sample in biochemical changes included in the research. Where in the highest average of improvement for the modulus of Lactic acid was estimated to be 16.07 and the lowest average of improvement for the modulus of LDH estimated to be $10.97 \%$ in relation to the research sample.

The two researchers refer the decrease of the average of concentration of Beta-Endorphins in blood to the positive effect of using the proposed training schedule. The proposed training schedule led to the improvement of muscular endurance and periodical respiratory endurance which, in turn, contributed in delaying signs of tiredness with regard to juniors. Consequently the secretion of Beta Endorphins hormone which is related to tiredness, exhaustion and tension decreases.

This conclusion is in accord with the conclusions of the studies of Angelo Poulos (2001) (24), Meyer (2001) (31) and others in assuring that when Beta-Endorphins increases the over load training increases. Meaning that whenever the junior's level of endurance improves, the level of the concentration of Beta -Endorphins decrease. Its occurrence is related to the occurrence of muscular tiredness.

At the same time, the two researchers refer the improvement of the ability of getting rid of the Lactic acid to the improvement of the traineeship condition in relation to the research sample.Concequently, the functional condition improved and that affected positively on the decrease of the average of accretion of Lactic acid in blood. In addition to the increase of the efficiency of LDH which transmute the Lactic acid to Perophic acid which gives the junior the power of resisting muscular tiredness.

This conclusion agreed with the conclusions of the studies of Wael Mohamed Kandil (1998) (22), Adel Abd El Menem (1999) (14), Bentley and others (2001) (25), Bruke and others (2001) (27) and Abeer Mohamed Shehata that the codified training schedules lead to the improvement of the functional condition of players. Consequently, the player's ability to get rid of Lactic acid in blood increases. 
This conclusion also harmonizes with what Sawka and others (2004) pointed out. They believe that the decrease of the concentration of Lactic acid in blood is an indication that the functional condition of the athlete improves and their ability to continue physical performance improves. (99-33)

Moreover, table no. (5) Conclusions manifested that there are some significant statistic difference at the level of 0.05 between the before and after training measurements for members of the research sample in LDH in favor of the after training measurement.

The two researchers refer the decrease of the average of LDH in blood to the decrease of the concentration of Lactic acid as a result of improving the juniors' endurance and the ability of getting rid of Lactic acid.Concequently, the secretion of LDH decreases because of the adaption of physical effort and the improvement of periodical endurance and periodical and respiratory endurance.

This conclusion goes well with the conclusions of the study of Laila Abd El Baky (1996)(17).She assures that continuation in a codified training is associated with effort adaption which decreases the secretion of Lactic acid which, in turn, works to get rid of Lactic acid and waste of assimilation.

Furthermore, this conclusion conforms to what Soad Kamal Taha (1993) and Salah Mansy (1994) pointed out. They high lighted that with the continuation of improving endurance for the athlete, his ability to discard Lactic acid and to decrease secretion of Beta-Endorphins and LDH enzyme improves. (96:11) (126:10)

Thereby, the rightness of the assumption of the first research is conformed. This assumption stipulated that : "the proposed training schedule for improving endurance (muscular ,periodical respiratory) affects in a positive way on biochemical changes (BETA-Endorphins Lactic acid $-\mathrm{LDH}$ ) in relation to squash junior under 15.If we caught a sight of table no. (7) we would find out significant statistic differences at the level of 0.05 between the before and after training measurements in favor of the members of the research sample of the perfection of forehand killing shot in squash sport and in favor of the after training measurement.
Moreover, table no. (8) Conclusions indicated the existence of some averages of improvements in favor of after training measurement for the research sample in the perfection of forehand killing shot in squash sport. Wherein the highest average of improvement for a modulus of the cross shot was estimated to be $90.79 \%$ and the lowest average of improvement for a modulus of straight length shot estimated to be $66.67 \%$.

The two researchers refer the improvement of the perfection of forehand killing shot to the effectiveness of the proposed training schedule on improving macular, periodical and respiratory endurance, which, in turn, gave the junior the ability to endure tiredness and to get rid of assimilation wastes (Lactic acid) and that, in turn, leads to the improvement of the level of dynamic performance.

This conclusion goes well with the conclusions of the study of Wael Mohd Ramadan (1998) (22), Adel Mohamed Abd El Menem (1999) (14) and Abeer Gamal Shehata (2002) (15).They assure that the improvement of the players functional condition reflects positively on the performance of atheletes.In this respect, Mohamed Aly El Kot (2006) points out the improvement of the player's functional condition and his ability to perform due to the decrease of Lactic acid after exerting effort.

Abou El Ela Abd El Fatah (1996) added that the improvement of the player's ability for enduring increases his ability to get rid of Lactic acid .Consequently, signs of tiredness delayed, hence, the dynamic performance of athletes improves. (35:1)

By that means, the rightness of the assumption of the second research is confirmed.This assumption stipulated that : "the proposed training schedule for improving endurance (muscular - periodical-respiratory) affects in a positive way on the perfection of forehand killing shot with regard to squash player under 15 .

\section{Conclusions:}

In the light of the objectives and assumptions of the research and within the framework of the sample of the research and its characteristics, in addition to depending upon results of statistic 
analysis and the discussion of these results, we came to the following conclusions:

1- The proposed training schedule for improving endurance affects positively on biochemical changes (Beta -Endorphins Lactic acid $-\mathrm{LDH}$ ) regarding the squash junior under 15 .

2- There are better averages of improvements in the training measurement than the before training measurement in biochemical changes (Beta - Endorphins - Lactic acid LDH) ranged between (16.07\%: 10.97\%) with regard to the squash junior under 15 .

3- The proposed training schedule for improving endurance affects in a positive way and with statistic significance on the perfection of forehand killing shot with respect to squash player under 15 .

4- There are better averages of improvement in the after training measurement than the before training measurement in the perfection of forehand killing shot with regard to the squash player under 15 . These averages ranged between $(90.79 \%$ :66.67\%).
Second: Recommendations:

On the basis of putting forward conclusions and discussing them, and in the light of results were achieved ' the two researchers recommended the following:

1- Considering seriously squash player's muscular, periodical , and respiratory trainings, as they have an effective influence on biochemical sides and have an effect on the perfection of forehand killing shot.

2- Following up the evaluation of training schedules on the basis of accurate biochemical measurements (Beta Endorphins -Lactic acid-LDH) with regard to the squash junior under 15 .

3- Supporting sports structures with medical analysis labs or with simple medical equipments to make use of them in the follow up, evaluation and improvement training schedules through measuring averages of concentration of (Beta Endorphins -Lactic acid-LDH ) in blood. 


\section{References:}

\section{First: Arabic References:}

1-Abou El Ela Ahmed Abd El Fatah (1996).Training load and Health of an athlete (Positives Risks) Al Fikr Al Araby publisher, Cairo.

2- -Abou El Ela Ahmed Abd El Fatah (1999): Medication in Sport Field Al Fikr Al Araby publisher, Cairo.

3-AL sayed Abd El Maksoud (1992): Theories of Sports Training and Endurance Physiology, Al Shabab AL Hor Printing shop, Cairo.

4-Ehab Saber Ismail (2009): "The Effectiveness of Visual Training on Some Attacking Talents for the squash player" master's degree, Faculty of Physical Education for boys, Zagazig University.

5-Bastwesy Ahmed Bastwesy (1999): Basic Principles and Theories of Sports training, Al Fikr Al Araby publisher, Cairo.

6-Baha'a Al Din Salama (2000): Biochemistry in Sports Field Al Fikr Al Araby publisher, Cairo.

7- Baha'a Al Din Salama (2000) Sports Physiology and physical Performance (Lactic of blood) Al Fikr Al Araby publisher, Cairo.

8- Gamal El Shafey (2001) Squash (its history-learning, training of talents, and rules of playing) Al Fikr Al Araby publisher, Cairo.

9- Hanfy Mukhtar (1988): Principles of Planning sports training schedules,Zahran Publisher ,Cairo

10-Saad Kamal Taha (1993): Sport and Principles of Biology, Al Maadi publisher.

11-Salah Mustafa Mansy (1994): Using measurements of blood Lactic to evaluate swimmers."Sports doctorate, Faculty of Physical Education for girls, Helwan University.

12-Aisha Mohamed Zeiton (1994): Practical Encyclopedia in Sports training (Biological and Biomechanics endurance) first edition, Book Center Publisher, Cairo.

13-Adel Abd Al Basir (1999): "sports training integration between theory and application, Al Motheda Book Shop, Port Said.

14- Adel Mohamed Abd El Menem (1999):'training schedule by means of Lactic endurance and its effect on some physiological and biochemical changes for short distance swimming", spots doctorate, Faculty of Physical Education for boys, Menia University.

15- Abeer Gamal Shehata (2002) : "the effectiveness of two styles of training loads on the on the concentration of Lactic acid and some physiological and physical changes in addition to 400 meter free style swimming ",sports doctorate, Faculty of Physical Education for girls ,Helwan University.

16-Essam Edin El Weshahy (1983): "the volley ball for juniors and pupils, Al Fikr Al Araby publisher, Cairo.

17-Laila Abd El Baky (1996) "The effect of physical effort on trans amines enzyme and LDH with regard to athletes of running and jogging and its relation with numerical levels" sports doctorate, Faculty of Physical Education for girls ,Helwan University.

18-Mohamed Ahmed Megahed (1998) "cinematic analysis for the forehand killing shot in squash." Master's degree "Faculty of Physical Education, Tanta University.

19- Mohamed Aly El Kot (2006): swimming between theory and application Arabic Center Publisher, Cairo. 
20-Munir Gerges Ibrahim (2004): "handball for all" Al Fikr Al Araby publisher, Cairo.

21-Wael El Sayed Kandil (1997): "setting tests groups for measuring special physical characteristics for squash players, Master's degree" Faculty of Physical Education, Helwan University.

22- Wael Mohd Ramadan : (1998) "proposed schedule to improve speed endurance and its effect on unareal sill and the level of numerical achievement for 800 meter running athletes Master's degree " Faculty of Physical Education,Helwan University.

\section{Second: Foreign References}

23-Alam Maryon Davis (1989): Fit for Squash manbovn, Hong Kong. 24-Angelo Poulus (2001): Beta Endorphin and Endurance during Exercise, Journal of Appl., Physiology

25-Bentley, et., al (2001): The Effect of Lactic acid and Secretion in blood during Exercise, Medicine Magazine.

26-Bullock, et., al (1991): physiology the national medical services for independent study, second edition, Hang Kong.

27-Burke, J., et., al (2001): Comparison of Effects of Twaintered Training Programmers on Lactate and Ventilatory Thresholds, British journal of Sports Medicine, England, Vol. 28.

28-Gold Farb, et., al. (1995): Response to Intensity and duration of Exercise, Med., Science Sports.

29-Ian Meleenwgie(1987): squash the sheills of the game. British ly the rowed press.

30-James. M. (1982): Human Biochemistry, tenth edition, London

31-Meyer, at., al. (2001): Effect of Endurance on Beta Endorphin Secretion, Journal of Science Sports.

32-Nick, H., Malcdon, C., (1994): Soccer Training, 4th heed, New York,

33-Sawka, M., Knowlion, R., \& Miles, P., (2004): Competition Blood lactate concentration in collegiate swimmers Eur., Journal of Appl. Physiology, Vol. 62.

34-Troup, D., (1991): Plasma Lactate and Recovery in Adult, Journal of Appl., Physiology. 